on the way, and their final successes, often accompanied by charming pen-pictures of the areas visited and of the orchids themselves. The photographs, several of which are coloured, are all taken in the field, and therefore show effectively the natural habitat of each species. Keys to the genera and species are supplied at the end, together with a glossary of scientific terms used. The features mentioned above, together with the excellent format, render the book a useful and attractive addition to any botanical library.

V. S. S.

\section{Classification of Ore Deposits.}

Ore Deposits of Magmatic Origin : their Genesis and Natural Classification. By Prof. Dr. Paul Niggli. Translated from the original German edition by Dr. H. C. Boydell. Revised and supplemented throughout by Dr. Niggli and Dr. R. L. Parker. Pp. xi +93. (London: Thomas Murby and Co.; New York: D. Van Nostrand Co., 1929.) $9 s .6 d$. net.

$\mathbf{P}$ ROF. NIGGLI has followed his important monograph of 1920 on the function of the volatile constituents in petrology by an interesting essay on their importance in the classification of ore deposits. He adopts the view that an ore is a rock and should be studied as such, and that " ore deposition is a part problem of magmatic differentiation in its widest sense". He regards as magmatic all products that arise originally from the interior of the earth, and holds that "magmatic processes are to no small extent involved in the formation " of even such materials as glass sands and those used for cement and pottery. He divides magmatic products into three kinds: the orthomagmatic, or directly igneous, to which some authorities limit the term; the pegmatitic-pneumatolytic; and the hydrothermal. He remarks that the meaning of the term pneumatolytic has been altered, since it was proposed by Bunsen for volcanic exhalations; but as the essential agent, according to Bunsen's conception, is superheated steam, the modern development seems justifiable. The author's introduction of the term orthomagmatic is useful, as its adoption would avoid the ambiguity as to the implication of the term magmatic.

The author is a master of the principles of physical chemistry, and his treatment of ore formation is throughout clear, though technical, and suggestive. He introduces many new terms, such as 'exogeospheric' for the processes of the atmosphere and lithosphere, and 'endogeospheric' for those of the interior, and 'telemagmatic' for operations that take place remote from the site of the magma.

The author lays stress on the threefold division of ores, based on depth and nature of formation, on geological age, and on geographical distribution. $\mathrm{He}$ applies to ores his well-known views on petrographic provinces, and adopts Pacific and Mediterranean groups of ores. That those terms are not used in a strictly geographical sense is shown by the remark that there are many Pacific provinces. His classification develops the well-established gradual passage from the deep-seated orthomag. matic to the superficial or hydrothermal ore deposits. He differs from many economic geologists in his conclusion that " complete sequences of ore deposits are connected with folding movements". He explains the poverty of the Alps in ore deposits as due to the movements which made the mountains having been promptly followed by the sinking of the area as a geosynclinal. There is much to be said for the alternative view that the ascent of the hydrothermal solutions takes place mainly along deep-seated normal faults in regions of tension.

The book refers briefly to a large number of ore deposits and there are naturally a few slips, such as the pre-Cambrian age of those of Mount Lyell, and reference to the titaniferous iron ore of Taberg in Sweden as an example of an orthomagmatic ore of great economic importance.

The careful translation by Dr. H. C. Boydell has been revised and supplemented by Prof. Niggli and Dr. Parker.

\section{Peruvian Antiquities.}

Dress and Ornaments in Ancient Peru : Archoological and Historical Studies. By Gösta Montell. Pp. viii $+262+3$ plates. (Göteborg: Elanders Boktryckeri A.-B.; London: Oxford University Press, 1929.) 15s. net.

T $T$ is characteristic of the cosmopolitan learn1 ing of our time that this study in Peruvian antiquity should be prepared at Gothenburg, translated into English, and published, with a generous Swedish subsidy, by the Oxford University Press. Besides the splendid ethnographical museum in Gothenburg over which Erland Nordenskiöld presides, more than a score of other museums and galleries have contributed material and illustrations.

For the cultures which preceded the Inca régime, the material is mainly archæological. A sufficient number of actual garments have been preserved by 